\title{
The Process of Communication in Decision-Making
}

\section{Cezarina Adina Tofan}

$\mathrm{PhD}$ in Economics, $\mathrm{PhD}$ in Engineering, Associate Professor, University of Pitesti, Faculty of Mechanics and Technology, Manufacturing and Industrial Management Department, Romania

\begin{abstract}
Negotiation represents a way of communication that has the ability to produce frequently the radical changes on the behaviour, attitudes and aspirations of the participants in the negotiation, in relation to the form, the amplitude of the approached issues and to the horizon of their possible solutions.

Through communication in negotiation, the solutions of the issues turn into decisions of the parties, which may lead to an agreement.
\end{abstract}

Keywords: communication, negotiation, decisions, business, professional ethics.

JEL Classification: M20, M21, M10, M14.

(C) The Author, 2017. This article is published with open access at ARMG Publishing.

\section{Introduction}

Chronologically, the interpersonal communication is the first human's spiritual instrument in his socialization process. Between the communication process and society, respective the human existence, there is a close relationship of dependency and interaction; the communication plays a major role in the daily life of each person, regardless of the complexity of their activities.

Negotiation is a specialized communication, which requires learning, experience, talent and principled. "Negotiation is a form of communication that involves a communicative, dynamic and an adjustment process for establishing the agreement in case of conflict of interests, whereby two or more parties, animated by different motives and having their own objectives, mediates their positions in order to reach a satisfactory mutual agreement" (Deac, 2002: 9).

Between all forms of communication, the negotiation is the only one that recognizes the pursuit of a priori interest. To be something other than selfish, the actions related to the negotiation must admit, from the beginning, that there is nothing more normal for a partner or partners to follow the same thing, but from their point of view - their interest. Reaching here, we are already far from confusion that might be made by some between negotiation and shopkeepers, not to mention the serious slide towards scam. For Gary Johns the negotiation is a decision making between interdependent parties that do not share identical preferences (Johns, 1998: 426). More specifically, it is the activity which attempts to arrive at a satisfactory exchange between the parties.

In negotiation, that is a democratic form of confronting the enemy (partner), the communication takes place between equals, meaning that the loser has nothing to negotiate, he cannot raise claims, all that it is given is the winner gift. A recorded axiom of Stefan Pruteanu based on the assertion "communication involving the power relations between partners and the transactions (exchanges)" taking place between them can be symmetrical or complementary. This means that the ideal of achieving the full equality rapport between interlocutors is utopian (Prutianu, 2000: 29).

The negotiator desires are as "the decisions that must get after adapting to the wishes of the other party; specifying that should be considered a hierarchy of the own wishes priorities, to be reported to the wishes of the other party" ". Of course, between the negotiator desires that must take into account, a considerable importance to have those goals without which we cannot be conceived the acceptance of an agreement, medium importance have goals to which we aspire, but whose touch is not decisive and the small amplitude importance have goals to which the negotiator hopes to accomplish, but that does not affect his essential expectations and aspirations.

\footnotetext{
${ }^{1}$ http://www.comunicare.codoban.ro/.
} 
It is significant that negotiators do not explicitly express their intentions and goals, because they cannot negotiate from the rigid positions only with the risk of reaching a deadlock of negotiation, into a communicational "dead end".

Register of possibilities in the negotiation offers the possibility of flexibly expression and conduct, but at the same time, and the chance to reach the end of negotiations, an agreement.

On the other hand, most important is the point of entry into negotiation. Regardless of where it starts a negotiation, after it, that will arrive in a very different position. Negotiation begins with an input position in the negotiation and ends with an output position.

A basic rule is that it should never accepted the original offer of opponent, because there is always another offer of another party, much better, which can be obtained through negotiation.

Also, it would be optimal for negotiator to have at least two offers, of which one should take into account the needs and major motivations, while the second should attach the secondary. Output point depends on the presumed limits to which we can reach an agreement. On the other hand, the relationship between the input and output point in a negotiation depends on the options which are available for negotiator and his communicator skills.

\section{Method}

To achieve the research there was used a specific method of direct quantitative research - the survey, a selective research, using the administered questionnaire "face to face", as a tool for gathering information.

The selective research as survey is one of the most frequently applied methods in the field. The survey provides to the decision makers the possibility to identify solutions for the faced problems or for using the existent opportunities. Apparently nothing easier than asking questions contained in a questionnaire, the survey means a challenge in ensuring a high degree of accuracy, relevance and representativeness of the data.

To determine the effectiveness of communication skills in negotiation, we conducted a survey based on a questionnaire applied to participants in negotiations in several economic entities.

Expected target in the research is to identify the elements that can disrupt the good development of negotiations and failing the proposed objectives.

\section{Results}

Regarding those participating in the evaluation, the analysis of the personal information highlights the following group structure: $65 \%$ male and $35 \%$ female (Figure 1).

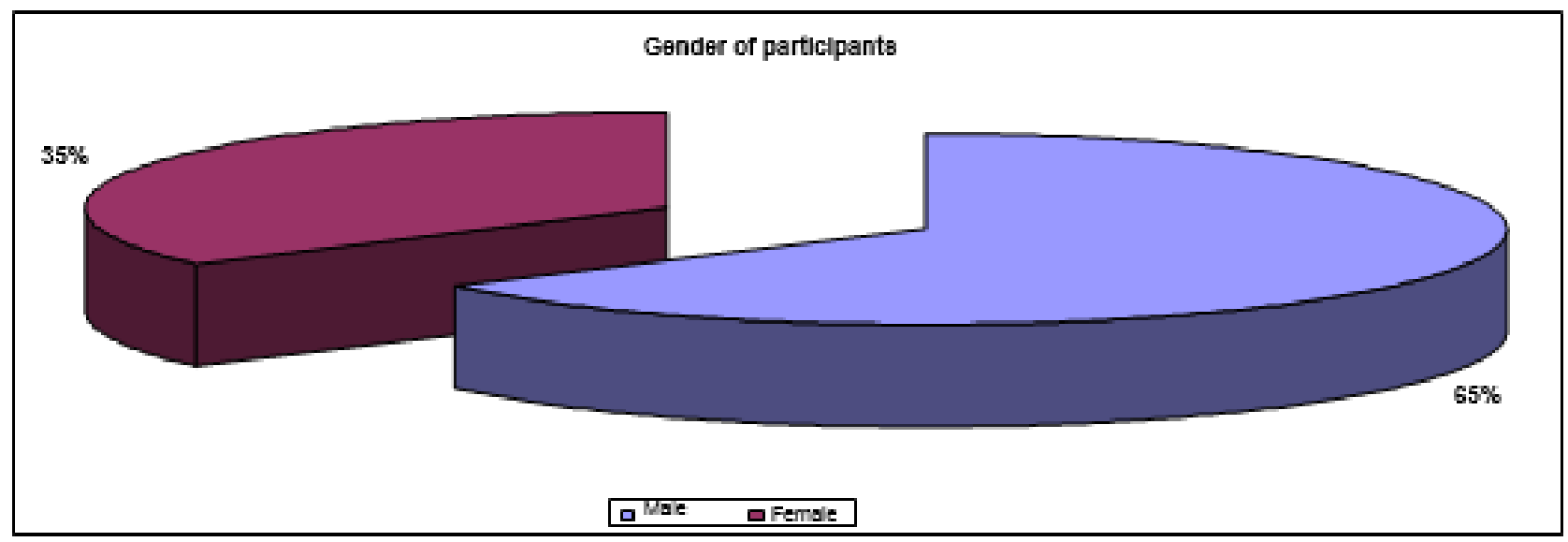

Figure 1. Structure of the participants group by gender

Age of the people who answered the questionnaire ranges between 20 and 60 years and the structure of respondents by age category is represented in the chart of Figure 2. 


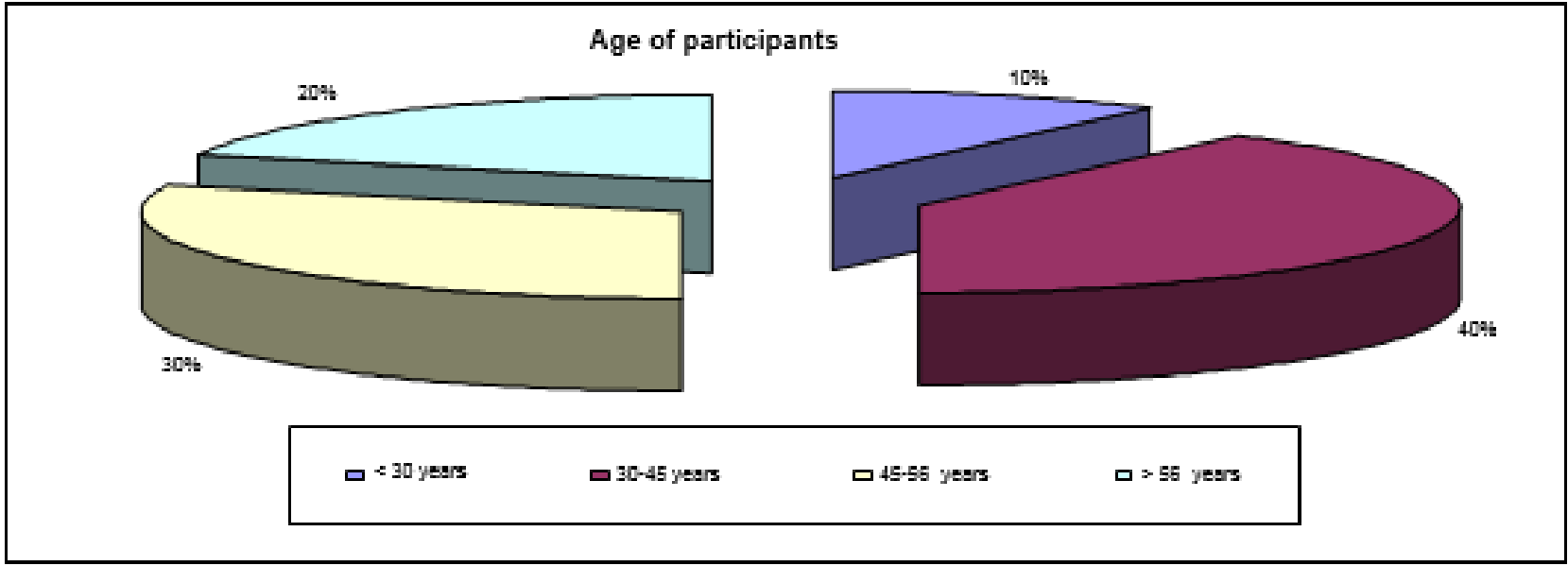

Figure 2. Structure of respondents by age category

Based on these characteristics of the group, it will be structured the points of each item in the collection instrument of the developed data and the questionnaire on identifying the required skills of a good negotiator.

This questionnaire is composed of 10 questions.

Each question has answer variants, less question 2, where each variant offered will be noted from 1 to 5 , where 1 means "not at all important" and 5 means "very important".

Analysing the answers to this questionnaire it has been given attention to the high degree of relevance in formulation of answers. The following items were considered to have influence the course of negotiations, all having the same degree of relevance.

The first question of the questionnaire is as follows:

\section{Choose the statement that best describes the place occupied by partners in the activities of your organization:}

$>$ The organization's activities may be conducted in good condition, without the involvement of the partners.

$>$ The organization always has a backup solution for replacing an underperforming partner.

$>$ The organization manages the Partner Relationship Management programs.

$>$ The organization strives to identify new partners to replace the current.

$>$ Organization honours its promises to customers using partners.

$>$ Organization could not perform the work without partners.

After processing the provided answers, we obtained the following graph:

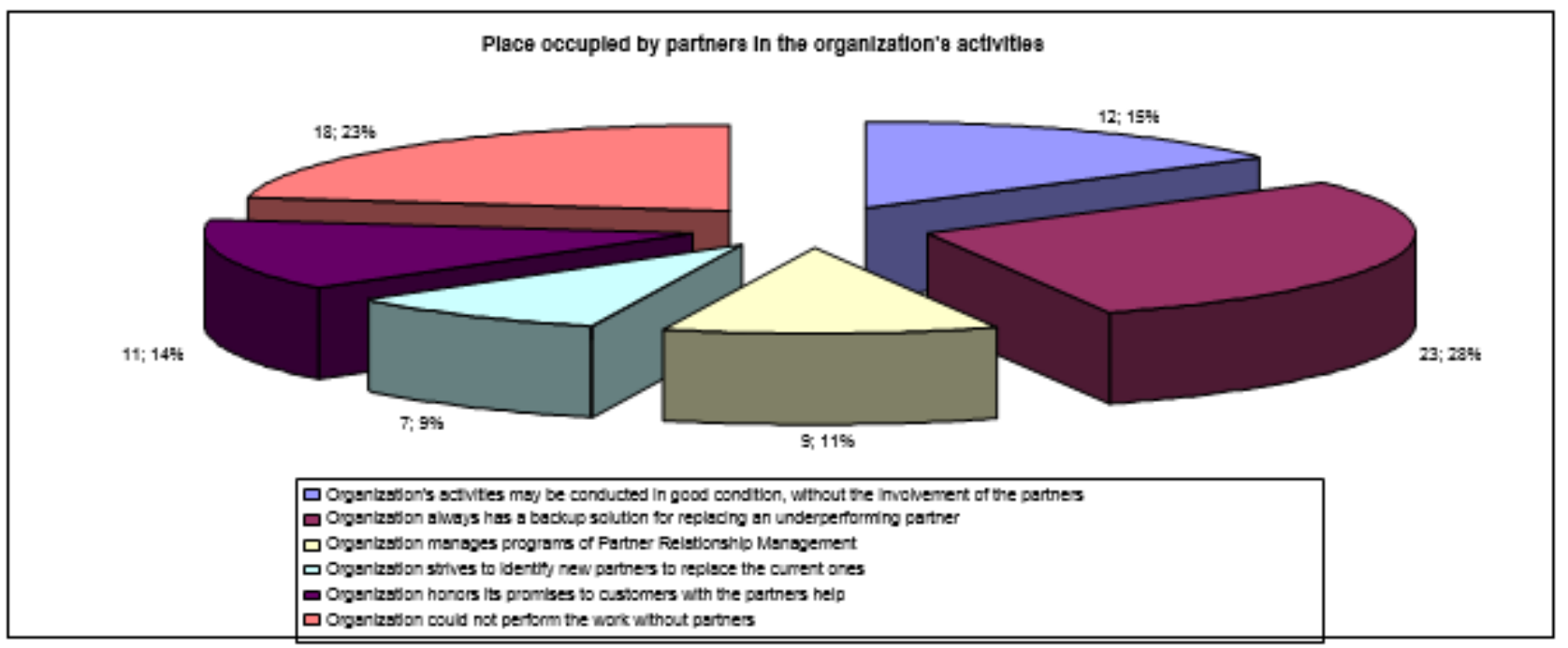

Figure 3. Place occupied by partners in the organization's activities

The next question in the survey, which has 8 items, based on the results of the analysis provided by the given answers were drawn a series of suggestive graphics for the decision makers. 


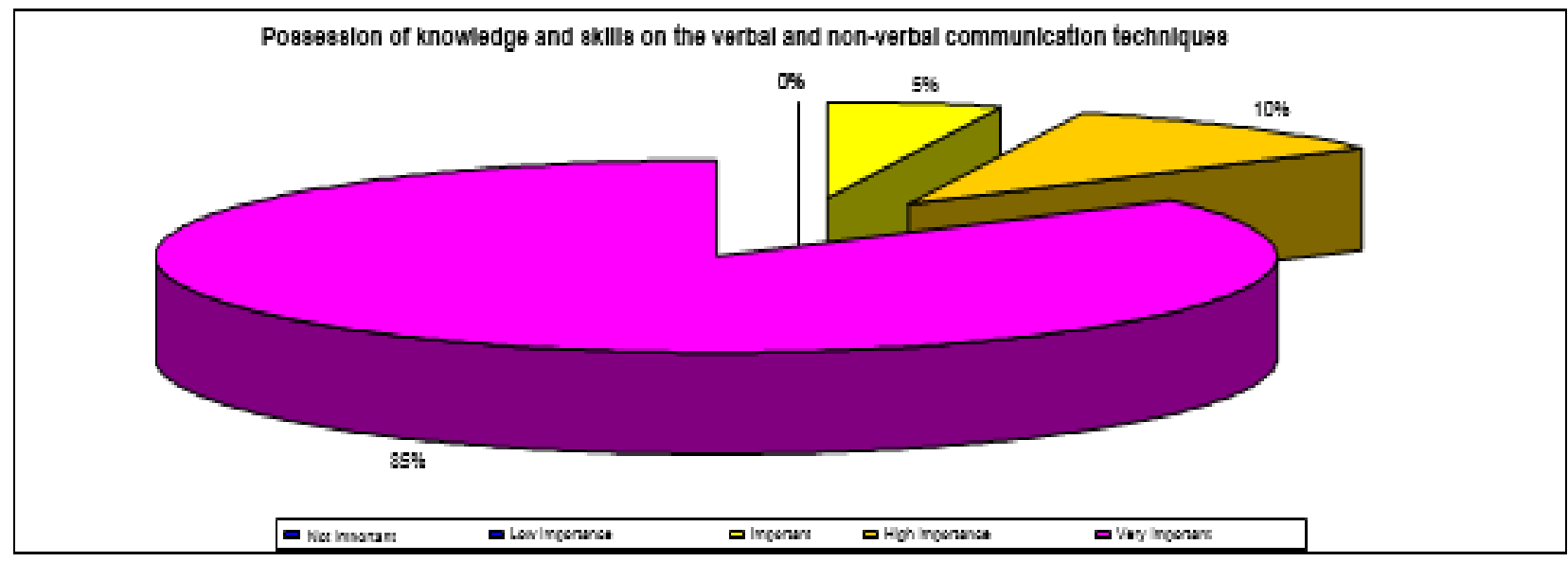

Figure 4. Possession of knowledge and skills on the verbal and nonverbal communication techniques

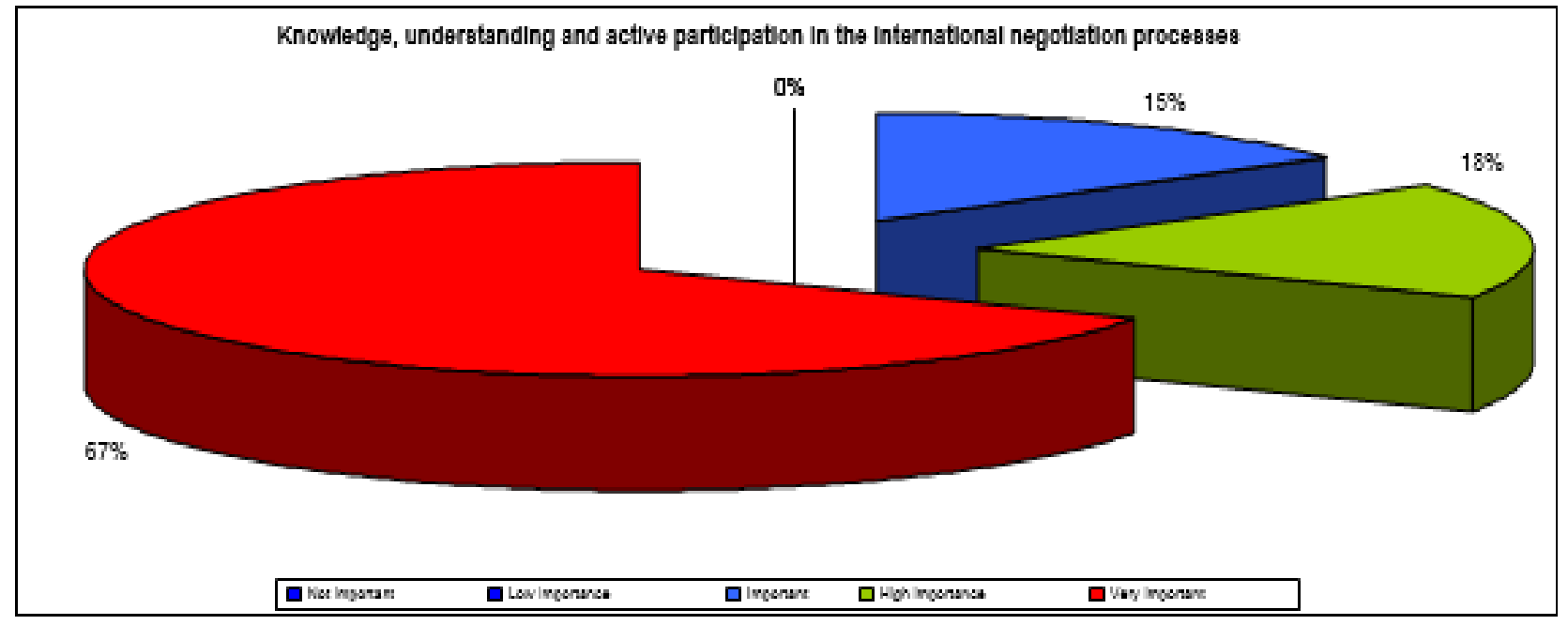

Figure 5. Knowledge, understanding and active participation in the international negotiation processes

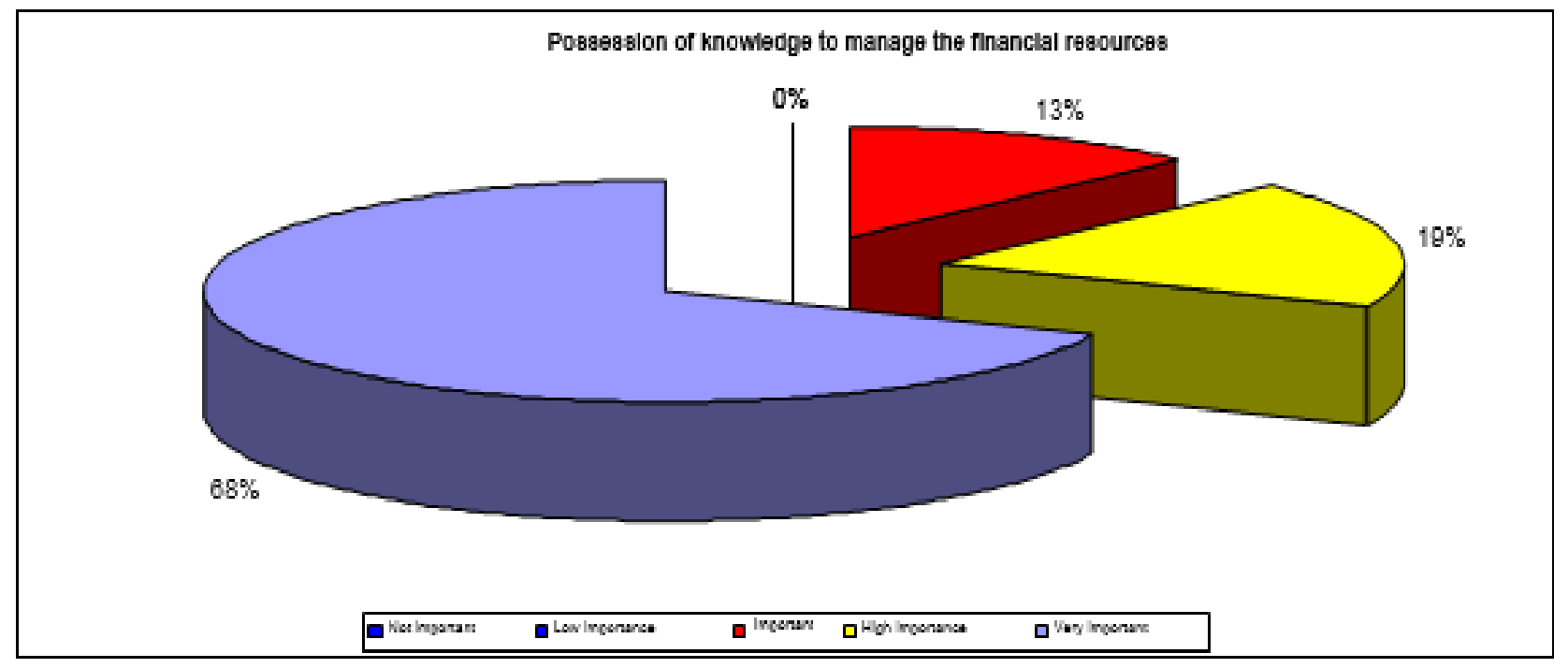

Figure 6. Possession of knowledge to manage the financial resources 
Easlly manage of the rlaks and opportunitles arlaling with the changes of some clrcumatances / characterlatica of the market

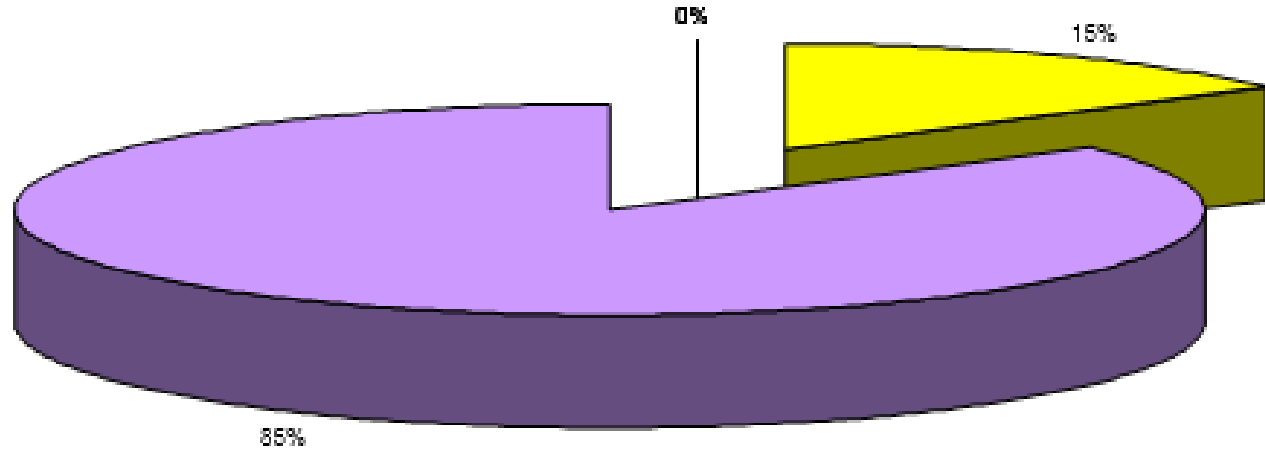

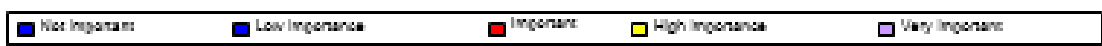

Figure 7. Easily manage of the risks and opportunities arising with the changes of some circumstances / characteristics of the market

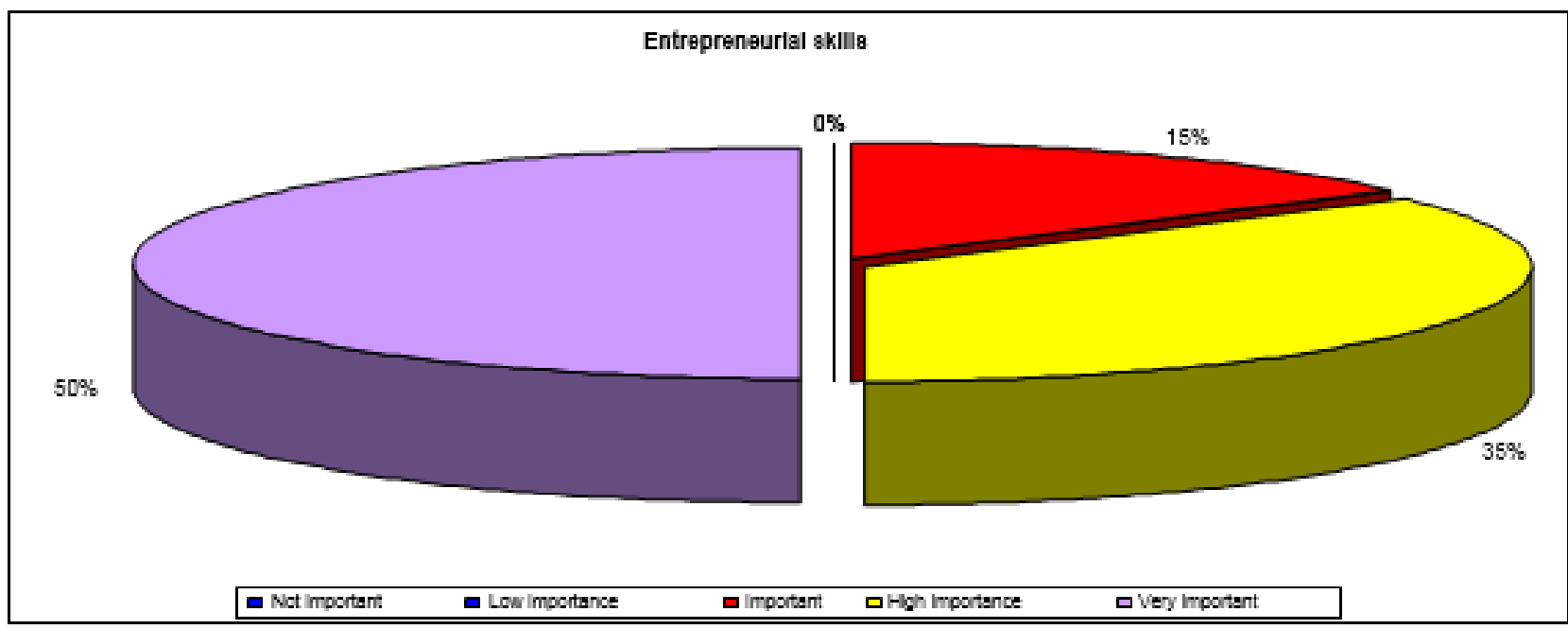

Figure 8. Entrepreneurial skills

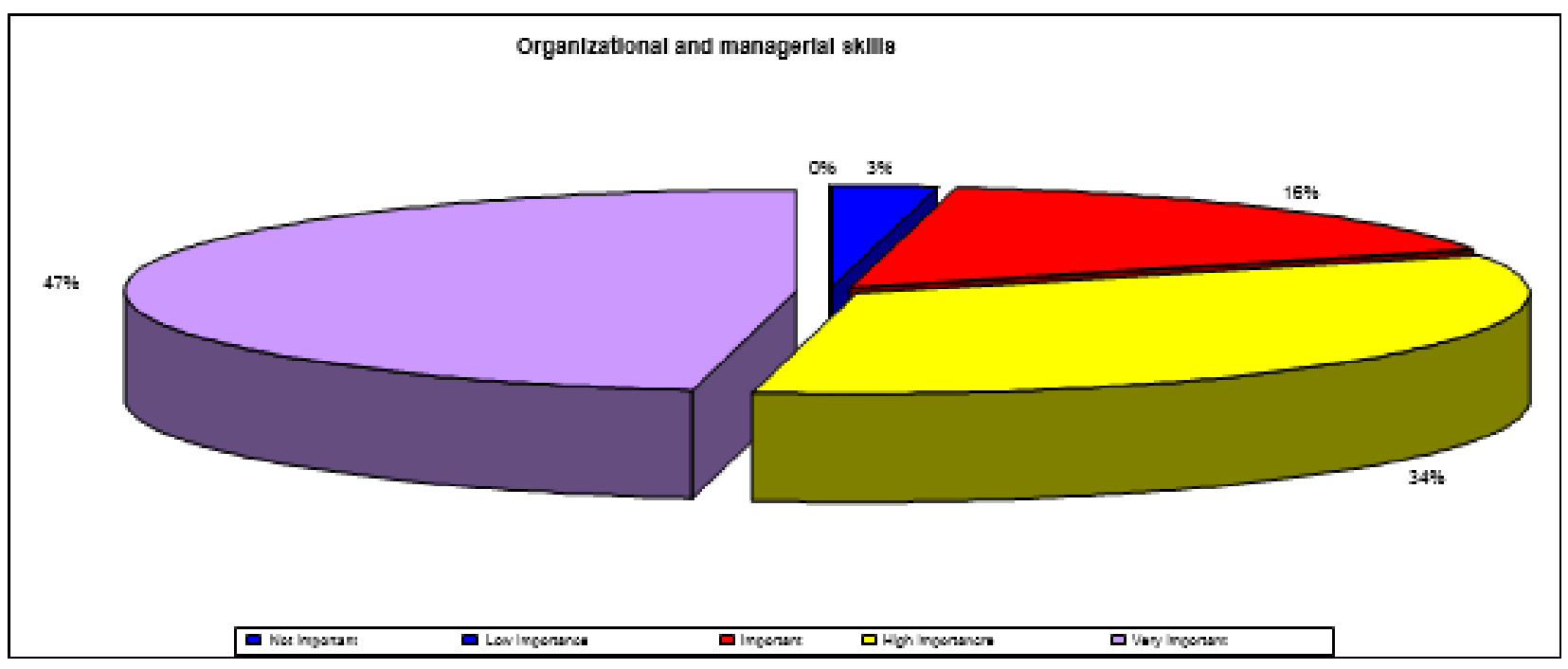

Figure 9. Organizational and managerial skills 


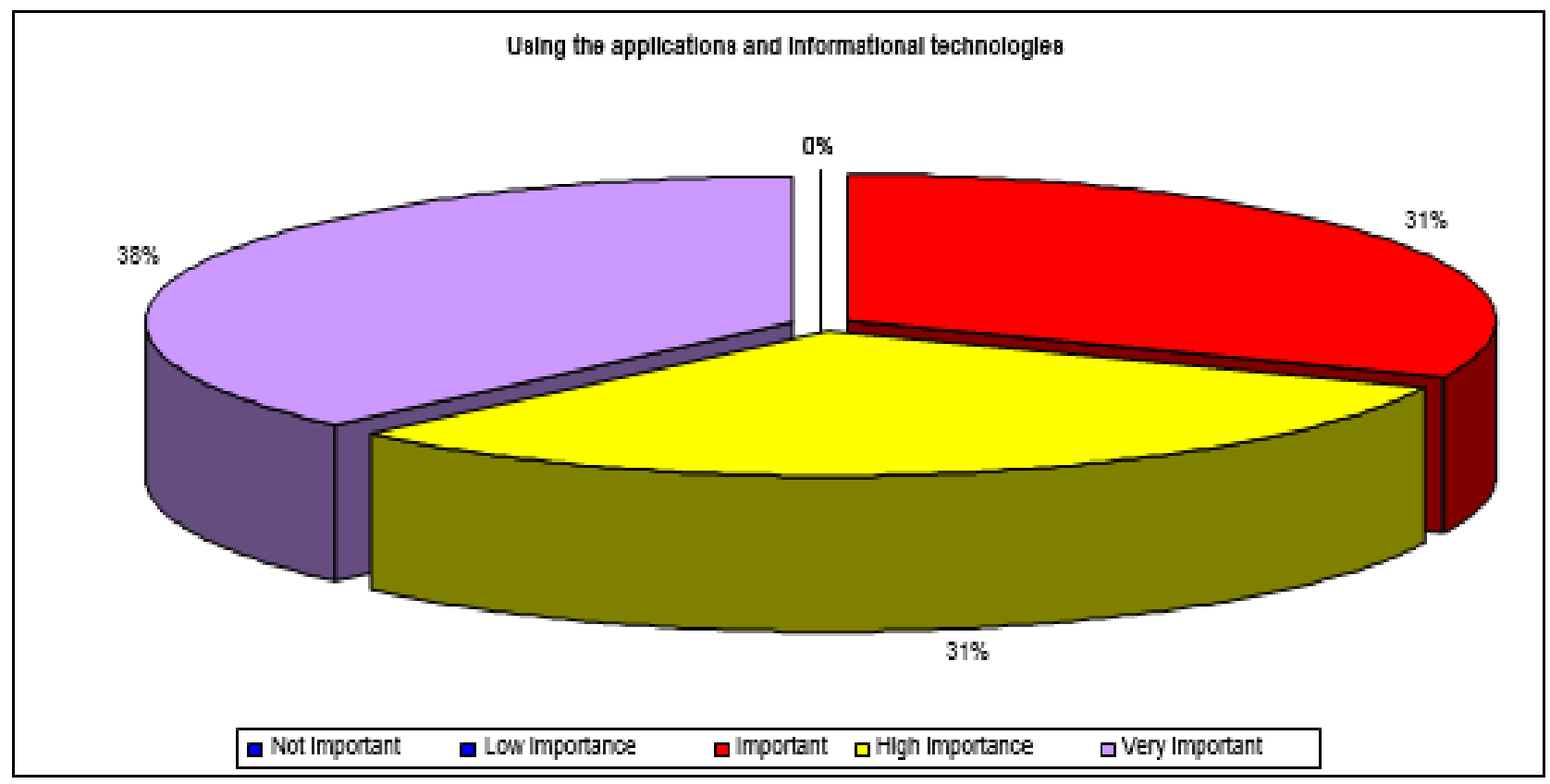

Figure 10. Using the applications and informational technologies

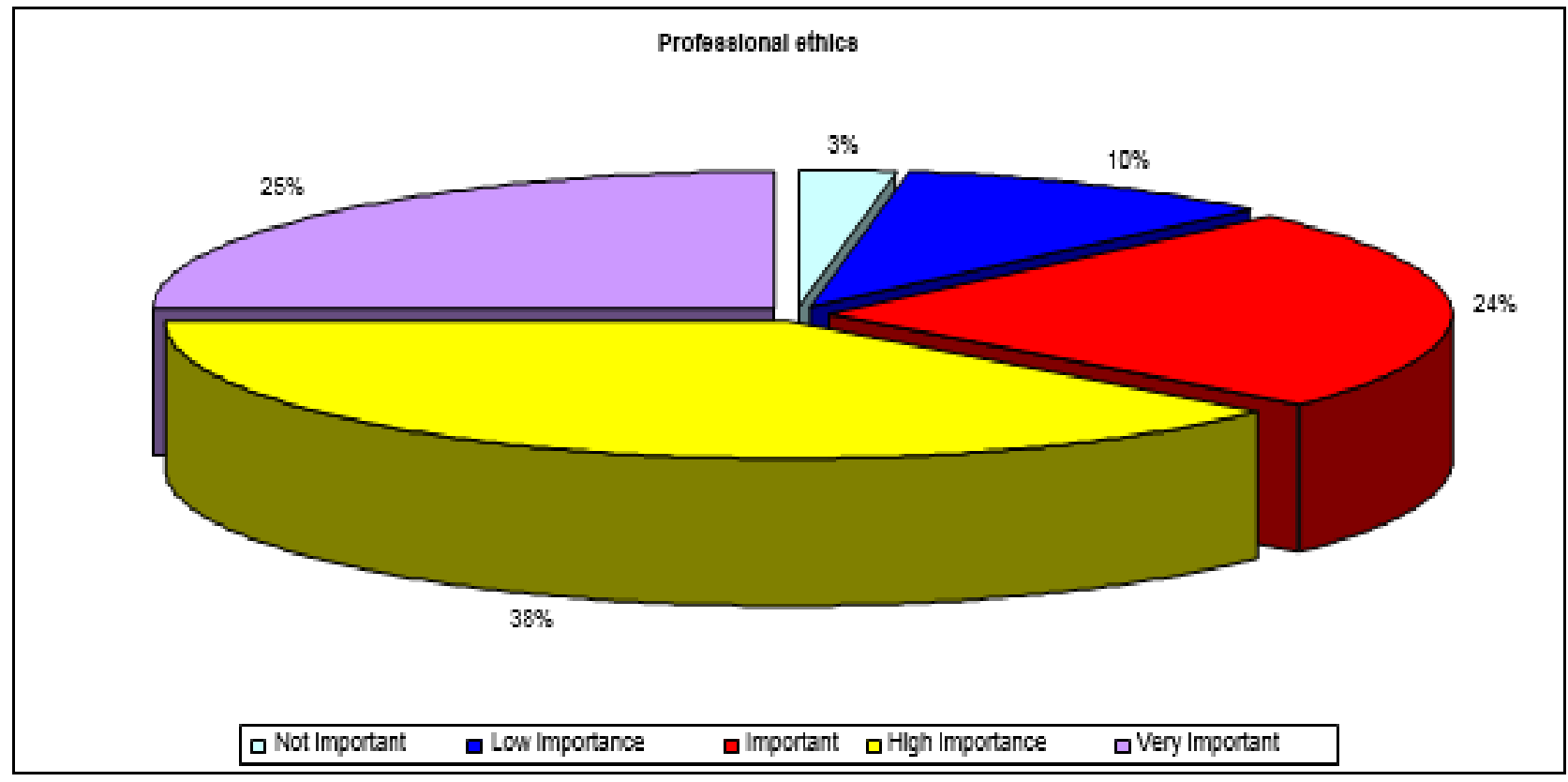

Figure 11. Professional ethics

Responses to the question in the questionnaire "Adjustment of your organization supply to the market developments involves one or more of the following measures", it is illustrated in Figure 12. 


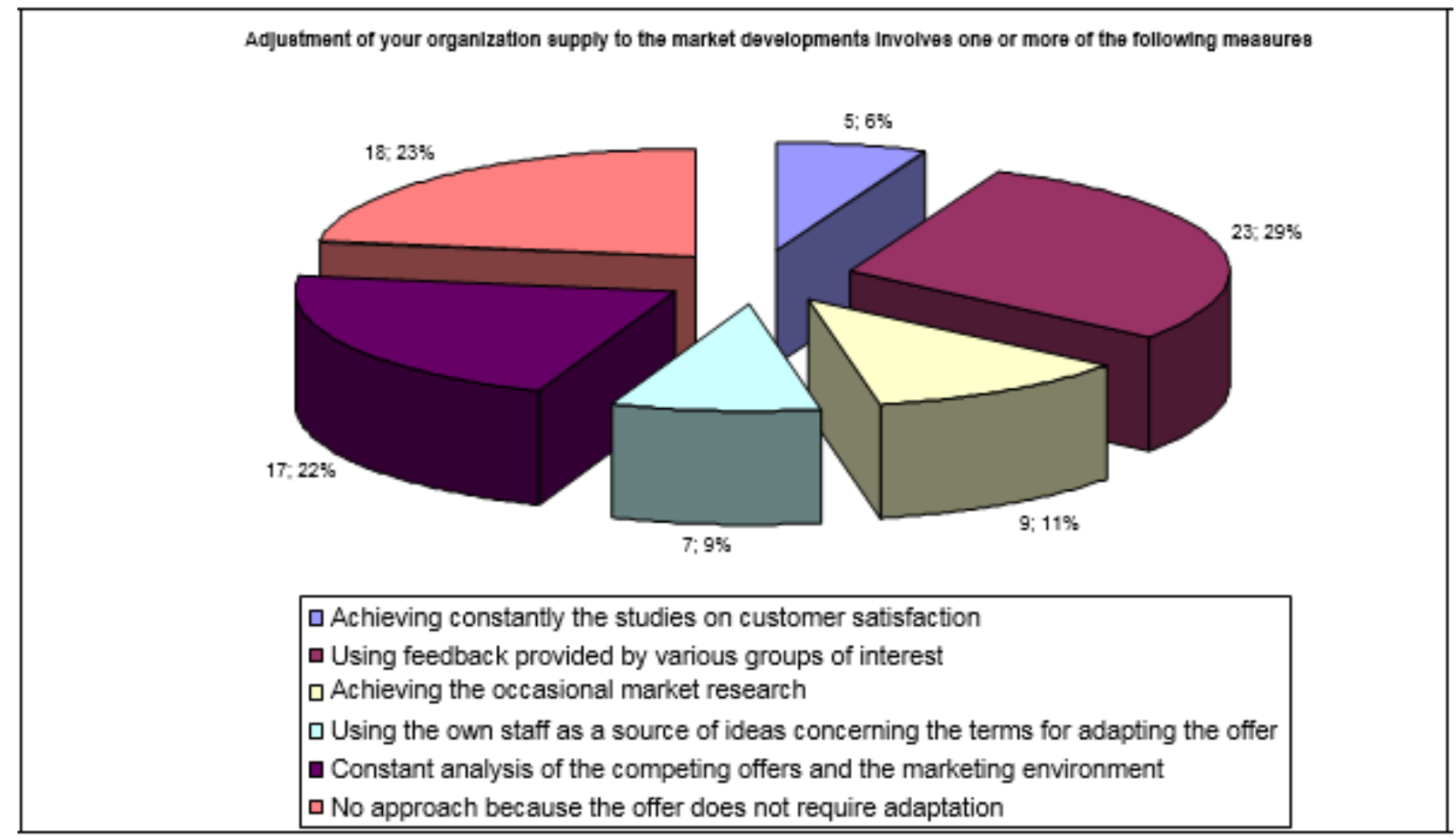

Figure 12. Adjustment of your organization supply to the market developments involves one or more of the following measures

One question in the survey is considered relevant for the conducted study "Select the steps to be taken as a negotiator, in promoting the organization and/or supply". To have a more suggestive image on the answers given to this question, we constructed a graph (Figure 13).

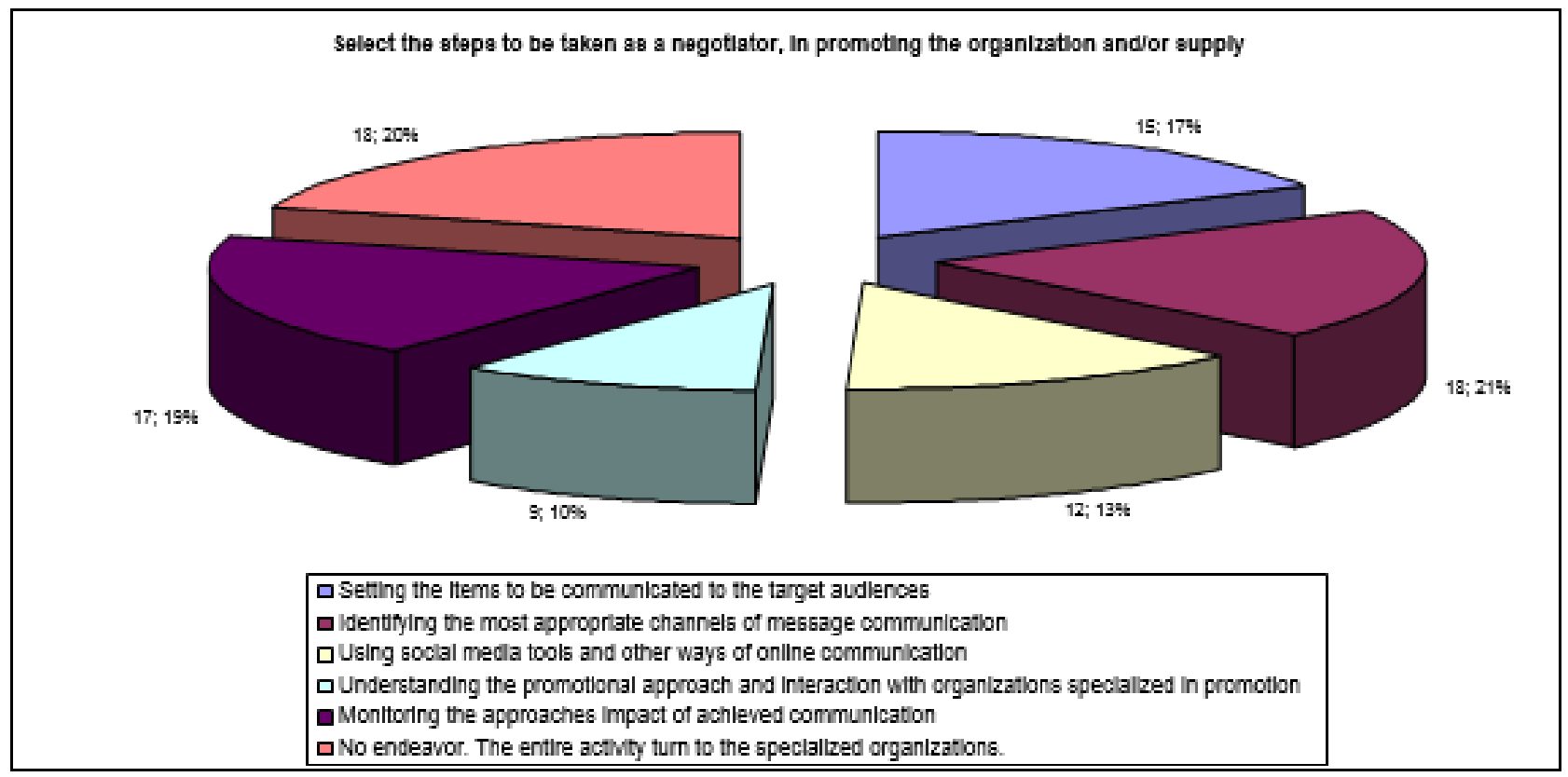

Figure 13. Select the steps to be taken as a negotiator, in promoting the organization and/or supply

All the persons who responded to the questionnaire agree with the statements of the items listed that define the advantages of this approach negotiation (Figure 14). 


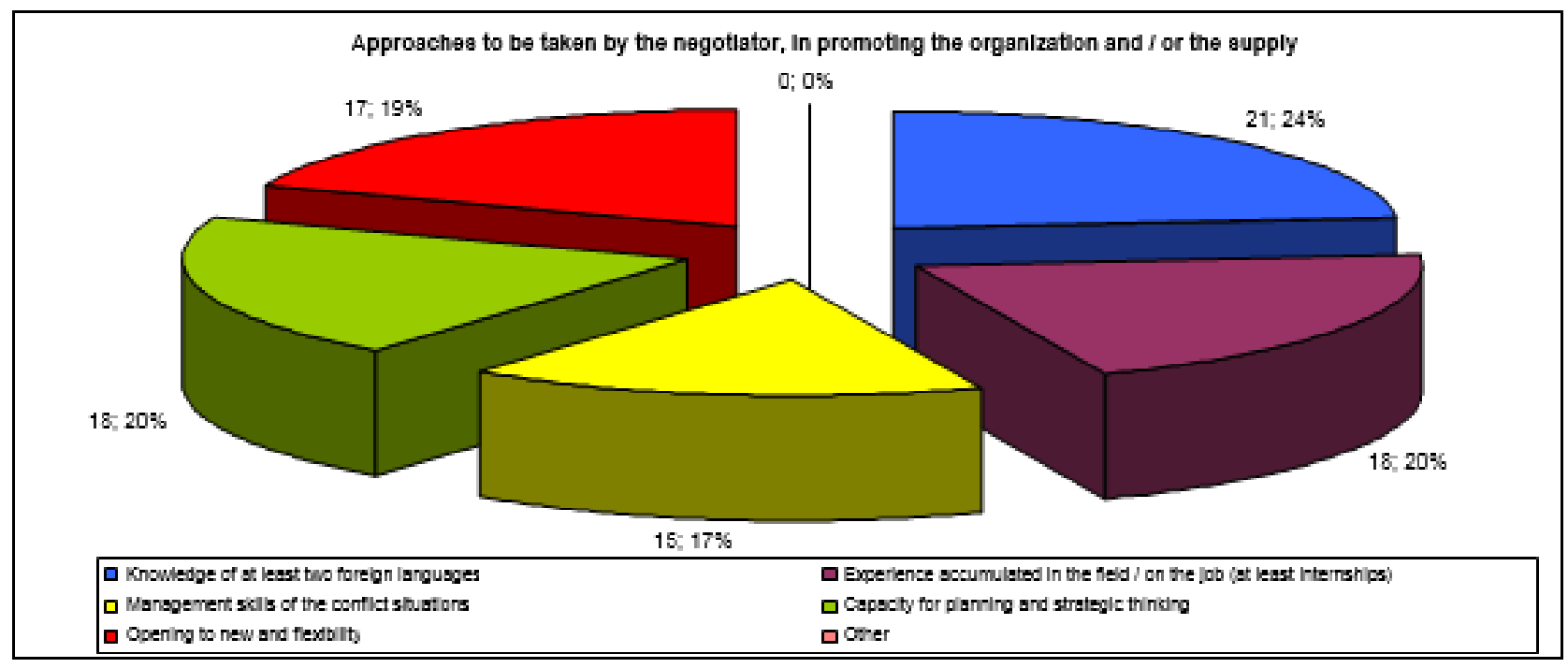

Figure 14. Advantages of the approach negotiation

Also, the questionnaire highlighted and the market size to whom it is addressed the investigated economic entities, illustrated in Figure 15.

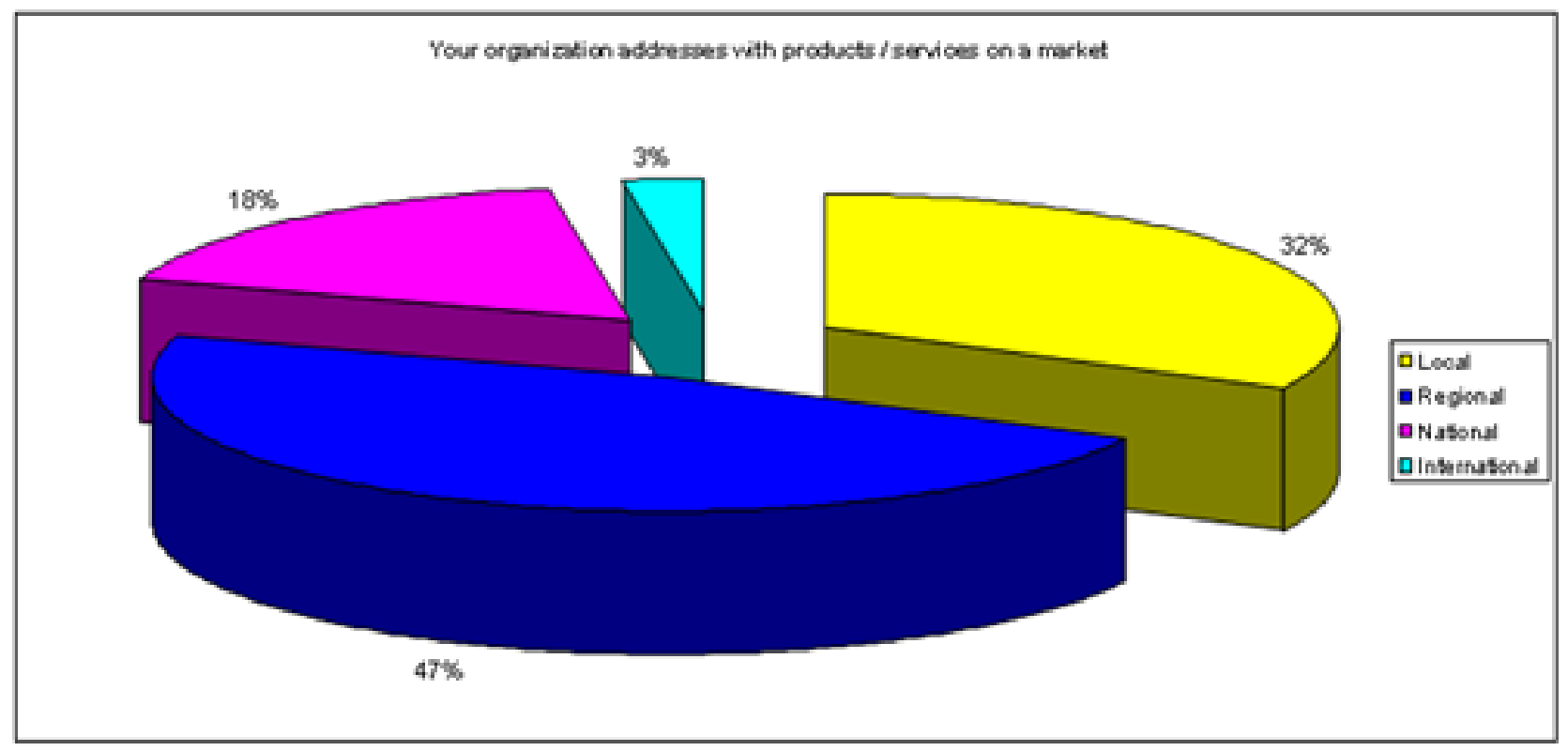

Figure 15. Market size

From processing the data provided by respondents in the survey there are drawn the most important skills required of a good negotiator and the close connection that they have with the communication elements.

The persons that were investigated mentioned a variety of determinants effects in the negotiation process, of the necessary communication skills, the increase of the negotiation quality, activity efficiency and correlation of the autonomy in taking decisions with a high degree of responsibility.

\section{Conclusions}

In the negotiation process, an essential moment is the choice of the modality to conduct the negotiations: importance should be given to establishing of some appropriate tactics that must consider a number of elements, such as the specific circumstances where the negotiation takes place, the purpose and means of the availability, actions of the negotiating partner, techniques used, the osage and their development.

If we use some tactics, techniques, tricks and negotiated schemes learned and practiced in advance, the chances to keep the control increase considerably. They help us to take over the initiative, but also to recognize the opponent strategy to properly administer the antidote. If we uncover the opponent tactics and call 
him by name, we unravel some of its power of negotiation. In addition, we have at hand a line of tactical premeditated action, a plan which deserves to respect it.

An effective tactic should be conceived so as to take account of the subjects on which is expected to exert pressure, of the intensity degree of the exerted pressure, of the arguments to be made for any counterargument and of the order to address the issues that will be negotiated.

\section{References}

1. Deac, Ioan (2002). Introducere în teoria negocierii, Editura Paideia, Bucureşti, p. 9.

2. Ephraim, Nikoi, Kwasi, Boateng (2013). Collaborative Communication Processes and Decision Making in Organizations. IGI Global.

3. Johns, Gary (1998). Comportament organizaţional, Bucureşti, Editura Economică, p. 426.

4. Mary C. Politi, Richard L. Street Jr. (2011). The importance of communication in collaborative decision making: facilitating shared mind and the management of uncertainty. J Eval Clin Pract, 17(4), 579-84. doi: 10.1111/j.1365-2753.2010.01549.x.

5. Paillart, I. (2003). Spaţiul public şi comunicarea, Bucureşti, Editura Polirom.

6. Păunescu, Loredana Maria (2014). Real needs of the labour market and the developing directions of human resources. Valahian Journal of Economic Studies. 5(3), 37-42.

7. Păunescu, Loredana Maria (2014). Strategies for implementing the professional training policies for the young alumni, Communication, Context, Interdisciplinarity [CCI] - III, Institutul de Studii Multiculturale Alpha, in parteneriat cu Universitatea "Petru Maior" din Targu Mures si Institutul de studii socioumane "Gheorghe Sincai" al Academiei Romane.

8. Prutianu, Ştefan (2000). Manual de comunicare şi negociere în afaceri, I, Comunicarea, Iaşi, Ed. Polirom, p. 29.

9. Rogojinaru, A. (2000). Teme de Relaţii Publice, Bucureşti, Editura Ars Docendi.

10. Roşca, L. (2000). Tehnici de comunicare profesională, Note de curs, Ed.ULB, Sibiu.

11. Vera, B. (1998). Antrenamentul comunicării sau arta de a ne înţelege, Gemma Pres.

12. http://www.comunicare.codoban.ro/. 